\title{
Anthocyanins, Phenolics, and Antioxidant Capacity of Vaccinium L. in Texas, USA
}

\author{
Wei Yuan ${ }^{1}$, Lijing Zhou ${ }^{2}$, Guangrui Deng ${ }^{1}$, Ping Wang ${ }^{1}$, David Creech**, $^{2}$ and Shiyou Li*,1 \\ ${ }^{1}$ National Center for Pharmaceutical Crops, Arthur Temple College of Forestry and Agriculture, Stephen F. Austin \\ State University, Nacogdoches, TX 75962, USA ${ }^{2}$ SFA Gardens, Arthur Temple College of Forestry and Agriculture, \\ Stephen F. Austin State University, Nacogdoches, TX 75962, USA
}

\begin{abstract}
Berries of Vaccinium spp. have long been an important source of food and pharmaceutical ingredients and are considered to have high antioxidant potential. Growing blueberries in Texas, United States is a substantial industry, but there is no report on their antioxidant capacity, total phenolics, and anthocyanins. This study evaluates antioxidant capacity and contents of total phenolics and anthocayanins in both fruits and leaves of 19 genotypes including five commercial cultivars and 11 selections of rabbiteye blueberry ( $V$. ashei) and southern highbush ( $V$. corymbosum hybrids), and three native species ( $V$. darrowii, V. arboreum, and V. fuscatum) grown in Nacogdoches, Texas. Significant variations in antioxidant capacity (as measured by FRAP) and contents of total phenolics and anthocyanins in fruit were observed among different species, cultivars or selections with less variation observed among individual plants of the same genotype. Our data from rabbiteye blueberry selections and cultivars support the hypothesis that antioxidant capacity is more highly correlated to total phenolics than anthocyanins. The analysis of five species indicates that antioxidant activity decreased during ripening but total phenolics contents tended to increase with maturity. Antioxidant capacity, total phenolics, and anthocyanin content did not change significantly during storage at $4^{\circ} \mathrm{C}$ or $-20^{\circ} \mathrm{C}$ for two weeks but decreased significantly when berries were oven dried at $65^{\circ} \mathrm{C}$ for $48 \mathrm{~h}$. Antioxidant capacity and total phenolics content in leaves of each genotype were 3 to 15 times higher than those in fruits.
\end{abstract}

Keywords: Blueberry, fruits, leaves, Vaccinium, antioxidant activity, total phenolics, anthocayanins.

\section{INTRODUCTION}

Edible berries are rich in antioxidants, anthocyanins (ACY) and other phenolic compounds that have demonstrated the ability to reduce risk for development or treatment of cancers [1-6], cardiovascular disorders [5, 7, 8], obesity, diabetes [9,10], aging-diseases [11, 12], urinary tract infections [13-16], and periodontal disease [15, 17, 18]. Berries and leaves of Vaccinium L. (family Ericaceae) have been an important source of food and pharmaceutical ingredients and are considered to have high antioxidant potential [3, 19, 20]. There are numerous products from Vaccinium leaf and fruit extracts utilized as dietary supplements in the world market. Fruit or leaf extracts of Vaccinium spp., particularly of bilberry ( $V$. mytillus L.) [2, 6], rabbiteye blueberry ( $V$. ashei Reade) [3], lowbush blueberry ( $V$. angustifolium Aiton) [21, 22], cranberry (V. macrocarpon Aiton) [23-25], and highbush cultivated blueberry (V. corymbosum L.) $[1,3]$ were found to induce apoptosis in cancer cells and to inhibit human leukemia $[2,23-25]$ and breast $[23,26]$, colon $[2,3$, 6, 23-25], lung [25], and prostate [21-23] cancer cells in

\footnotetext{
*Address correspondence to these authors at the National Center for Pharmaceutical Crops, Arthur Temple College of Forestry and Agriculture, Stephen F. Austin State University, Nacogdoches, TX 75962, USA; Tel: 936-468-2071, 936-468-5600; Fax: 936-468-7058;

E-mail: lis@sfasu.edu

**SFA Gardens, Arthur Temple College of Forestry and Agriculture, Stephen F. Austin State University, Nacogdoches, TX 75962, USA;

E-mail: dcreech@sfasu.edu
}

vitro. Fruit extracts of some Vaccinium species exhibited anticarcinogenic activity [4]. The leaf, fruit, and stem extracts of the lowbush blueberry and leaf extract of $\mathrm{V}$. bracteatum Thunb. indicated an opportunity for use as a complementary anti-diabetic therapy $[9,10]$. Cranberries (particularly in the form of cranberry juice) have been widely used for several decades for the prevention and treatment of urinary tract infections (UTIs) [27]. Research suggests that its mechanism of action is preventing bacterial adherence to host cell surface membranes [28]. Cranberry is a safe, welltolerated herbal supplement that does not have significant drug interactions [28]. Several recent clinical studies have demonstrated that cranberry and blueberry fruit or fruit juice may be a valuable therapeutic choice in the treatment of UTIs [13-16, 29]. Tannins isolated from cowberry (V. vitisidaea L.) exhibited antioxidant activity and antimicrobial activity, and could be used for the treatment of periodontal disease $[17,18]$. Recently, it was found that proanthocyanidin from blueberry ( $V$. virgatum Aiton) leaves possessed strong suppressive effects against Hepatitis $C$ virus subgenome expression in a replicon cell system [30]. Mice treated with polyphenol-rich extract of wild blueberry exhibited a significant improvement in learning and memory [12]. Several European studies indicated an improvement in night vision in humans with a variety of bilberry supplements. However, this has not been supported by some American clinical studies [31, 32]. To date, many medicinal investigations are still in the early stages, and thus the potential pre- 
ventive and therapeutic effects of Vaccinium products for most diseases are not conclusive and well-designed clinical studies are still needed.

Antioxidant capacity (AC) in Vaccinium with variables including varieties, cultivation, process, and storage has been of interest to consumers and the industry. The AC of Vaccinium (as determined by oxygen radical absorbance capacity (ORAC) or ferric reducing antioxidant power (FRAP)) is primarily due to total phenolics (TPH) [19, 20, 33]. Among phenolics, ACY is of particular interest because of their frequent occurrence in crops considered to have high nutritional value. ACY are water-soluble pigments responsible for red, purple, and black colors of Vaccinium berries. ACY is composed of an aglycone anthocyanidin and a sugar moiety mainly attached at the 3-position on the C-ring, e.g., delphinidin, cyaniding, petunidin, peonidin, pelargogidin, and malvidin [34]. Other major phenolics include gallic acid, $p$ hydroxybenzoic acid, caffeic acid, $p$-coumaric acid, ferulic acid, ellagic acid, (+)-catechin, (-)-epicatechin, myricetin, quercetin, and kaempferol [19].

It has been reported that TPH content and AC of Vaccinium are significantly affected by genotype and growing season [20, 33, 35-38]. TPH and ACY contents are more affected by genotype than growing season, whereas $O R A C_{F L}$ values are more affected by growing season [35]. Wild berries usually have much higher nutritional values than those in cultivation [20,39]. ORAC and TPH levels in leaves are significantly higher than in fruits of highbush blueberry [40]. Recently, there have been some studies of extraction and purification of some flavonoids or ACY from leaves of alpine bilberry (V. ultiginosum L.) [41-44] and sea bilberry (V. bracteatum Thunb.) $[45,46]$.

Investigations on $\mathrm{AC}, \mathrm{TPH}$, and $\mathrm{ACY}$ contents in Vaccinium are numerous in the last decade. However, existing research is primarily restricted to certain species grown in North America, Europe, East Asia, and Australia, e.g., lowbush wild blueberry [20, 33, 39, 47-50], highbush cultivated blueberry $[20,33,36,39,40,47,51-58]$, half-highbush blueberry $(V$. angustifolium $\times V$. corymbosum $)$ [54], rabbiteye blueberry $[20,33,51]$, bilberry [20, 59], black huckleberry (V. membranceum Douglas ex Torr.) [33, 54, 60], cascade huckleberry ( $V$. deliciosum Piper) [54, 60], velvetleaf blueberry ( $V$. myrtilloides Michx.) [33, 50], oval-leaf blueberry ( $V$. ovalifolium Smith) $[33,54,60]$, evergreen huckleberry (V. ovatum Pursh) [33, 54], cranberry [8], wild cranberry (V. oxycoccus L.) [54], red huckleberry (V. parvifolium Smith) [33, 54], V. reticulatum Smith [61], V. calycinum Smith [61], alpine bilberry [41-44, 54], cowberry [17, 62], sea bilberry $[10,46]$, and Caucasian blueberry (V. arctostaphylos L.) [63].

The United States produces about $60 \%$ of the world blueberry production with 199,127 metric tons reported in 2008 [64]. There are more than 63,000 ha of blueberries in the United States, and the leading states in blueberry production are Maine, Michigan, New Jersey, North Carolina, Oregon, Washington, Georgia, and Florida [64]. Studies in the United States are primarily on wild or cultivated blueberries in Northeast or Pacific Northwest [20, 33, 39, 40, 47, 48, 50, $53,54,65]$. There are only a few studies involving the nutraceutical properties of blueberries grown in the southern United States (e.g., Georgia, Florida, and Arkansas), e.g., southern highbush blueberry (V. corymbosum hybrids, introgressed with Darrow's blueberry (V. darrowii Camp.)) [19, 66] and rabbiteye [19, 33], but none from Texas. Existing reports on the relationship of fruit size and $\mathrm{AC}$ are somewhat contradictory [20, 33, 39, 40, 47, 67, 68] and further investigation is needed to clarify their effects. Vaccinium leaf extracts could be an important source of pharmaceutical products. However, most studies on AC, TPH, and ACY contents of Vaccinium focus on fruits rather than leaves. Long-term frozen storage of blueberries has not significantly affected the AC, TPH, and ACY [56, 65, 69]. It was further reported that the ACY content in dried blueberries is reduced in comparison to that found in fresh blueberries, while AC of the extracts did not differ from that of the fresh fruit [69]. Little is known, however, about the effect of storage process on the content of phenolic compounds of blueberries. This problem must be addressed in the development of blueberry extract products.

This study is to evaluate AC, TPH, and ACY contents in both fruits and leaves of major commercial cultivars in Texas and some important selections. Changes in $\mathrm{AC}, \mathrm{TPH}$, and ACY contents in fruits by different storage methods were also investigated. Data on both cultivars and storage method will provide groundwork for the development of Vaccinium pharmaceutical products (both berries and dietary supplement products) with high antioxidant activity and nutritional level for domestic and overseas markets.

\section{MATERIALS AND METHODS}

\section{Chemicals}

2,4,6-tripyridyl-s-triazine (TPTZ), gallic acid, Folin \& Ciocalteu's phenol reagent were purchased from SigmaAldrich (St. Louis MO). Sodium acetate, $\mathrm{FeCl}_{3} \cdot \mathrm{H}_{2} \mathrm{O}$, ACS grade methanol and other unspecified reagents were purchased from VWR International (West Chester, PA).

\section{Sample Preparation}

Fruit and leaf samples of Vaccinium were collected from three plants each of 19 genotypes including five commercial cultivars, 11 selections of $V$. ashei and $V$. corymbosum, and three native species ( $V$. darrowii Camp., $V$. arboreum Marsh., and V. fuscatum Ailton) in Nacogdoches, Texas, USA in 2009 and 2010, Fig. 1, Table 1). The five commercial cultivars included 'Brightwell', 'Climax', 'Tifblue', 'Premier', and 'Powderblue' (rabbiteye blueberries ( $V$. ashei), and 11 breeding selections including rabbiteyes MS 63, T 342, and T 38 and the southern highbush (V. corymbosum hybrids) MS 108, MS 122, MS 179, MS 231, MS 343, MS 546, and MS 548, Darrow's blueberry ( $V$. darrowii) ('Nativeblue'), and wild sparkleberry ( $V$. arboreum) (leaves only) and black highbush blueberry (V. fuscatum, synonym: $V$. arkansanum Ashe). In addition, three commercially available samples ('Organic', 'Driscolls', and 'Naturipe') were purchased from a local grocery store in Nacogdoches, Texas, USA.

To investigate the relationship between fruit size and $\mathrm{AC}$, TPH, and ACY contents, mature berries from each of the three plants of 'Tifblue' and 'Premier' were divided by berry size. Berry size was determined by counting the number of berries per $100 \mathrm{~g}$ of sample. 


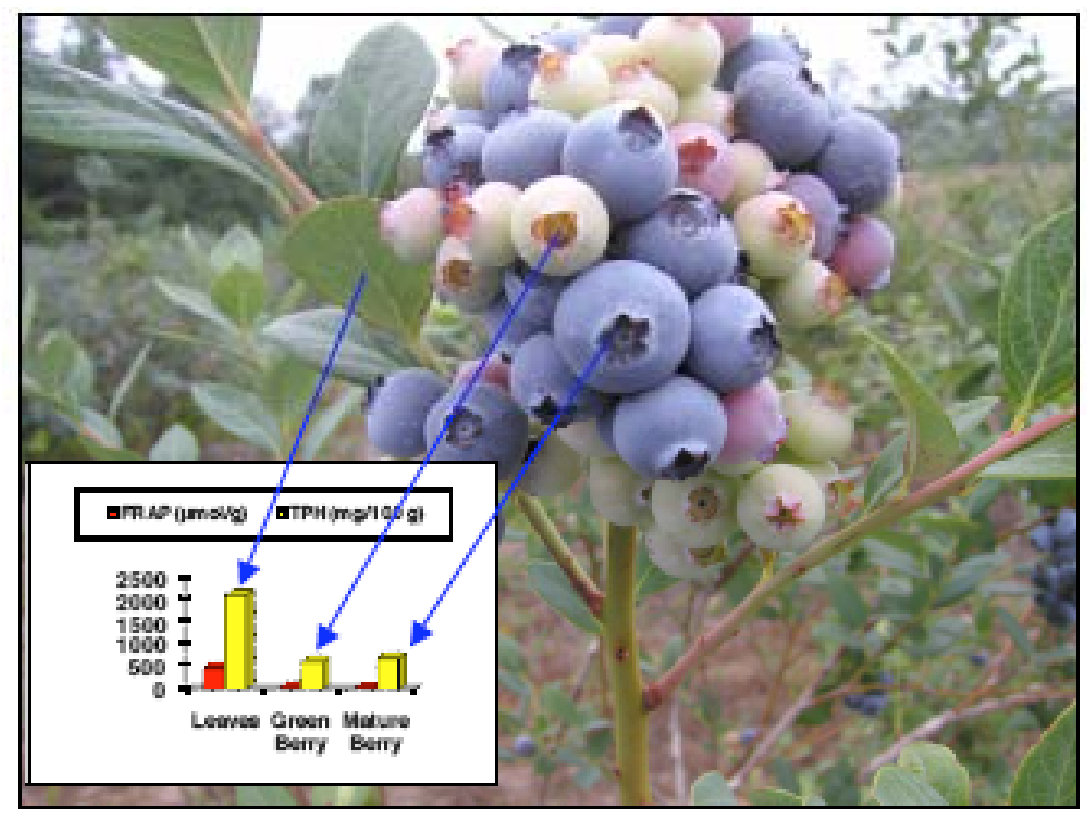

Fig. (1). Antioxidant capacity (AC) (in measurement of FRAP) and total phenolics (TPH) contents in immature and mature blueberries (photo by S.Y. Li).

Fruit samples of each collection were divided into four groups for different treatments: fresh (extracted and analyzed within $3 \mathrm{~h}$ ), stored at $4^{\circ} \mathrm{C}$ for two weeks, frozen at $-20^{\circ} \mathrm{C}$ for two weeks, and dried at $65^{\circ} \mathrm{C}$ for two weeks. Leaf samples were collected in the morning and freshly extracted and analyzed the same day.

Ten gram berry or leaf samples were added to $50 \mathrm{~mL}$ conical tubes and amended with 1:1 (w/v) ice-cold acidified methanol $(0.1 \% \mathrm{HCl})$. The samples were then homogenized with a Pro250 homogenizer (Pro Scientific Inc, Monroe, CT, USA) for $1 \mathrm{~min}$ After $30 \mathrm{~min}$, the homogenate was centrifuged under $3000 \mathrm{rpm}$ for $10 \mathrm{~min}$. $1.5 \mathrm{~mL}$ supernatant was transferred to eppendorf tubes and centrifuged at 14,000 rpm for $15 \mathrm{~min}$. The supernatant was diluted for further analysis, normally $100 \times$ for ferric-reducing ability of plasma (FRAP) assay and total phenolic assay and $20 \times$ for anthocyanin content assay.

\section{Antioxidant Capacity (AC) Assay}

The FRAP assay was performed as described by Benzie and Strain (1996) [70] and adapted for using 96-well plate spectrophotometer. Briefly, the antioxidants reduce ferric/TPTZ complex to a blue-colored ferrous form at $37^{\circ} \mathrm{C}$ in pH 3.6 sodium acetate buffer. The increased absorbance at $593 \mathrm{~nm}$ is proportional to the ferric reducing antioxidant power. The results were expressed as micromoles $(\mu \mathrm{mol})$ of ferric iron reduced per gram fresh fruit.

\section{Total Phenolics (TPH) Content}

The Folin-Ciocalteu method [71] was used to determine total phenolic content as described by Singleton and Rossi in 1965. An adaptation was made to use a 96-well microplate. After 120 min incubation for color development, absorption was read at $755 \mathrm{~nm}$ by a $\mu$ Quant spectrophotometer (BioTek Instruments, Inc.). Results are expressed as $\mathrm{mg}$ gallic acid equivalents $/ 100 \mathrm{~g}$ material.

\section{Total Anthocyanins (ACY) Content}

ACY content was determined by AOAC official $\mathrm{pH}$ differential method [72]. Results are expressed as mg cyanidin 3 -glucoside equivalents $/ 100 \mathrm{~g}$ fresh fruit using a molar extinction coefficient of 29,600 .

\section{Sugar Contents}

Total sugar was determined by a modified phenolsulfuric acid method [73]. On a 96-well plate, the following solutions were added successively: $40 \mu \mathrm{L}$ standard glucose solution, $20 \mu \mathrm{L} 5 \%$ phenol, $140 \mu \mathrm{L}$ concentrated sulfuric acid. The plate was then incubated at $85^{\circ} \mathrm{C}$ for $50 \mathrm{~min}$. After cooling to $25^{\circ} \mathrm{C}$ for $30 \mathrm{~min}$, the plate was read under $490 \mathrm{~nm}$ with BioTek $\mu$ Quant Microplate Spectrophotometer (Winooski, VT). To establish a standard curve of linear correlation, a series of standard glucose solutions at 20,50,70, 100, 250,375 , and $500 \mu \mathrm{g} / \mathrm{mL}$ were prepared using $100 \mathrm{~mL}$ volumetric flasks. Total sugar content of the berry samples were calculated with the established standard glucose curve.

\section{Statistical Analysis}

While an ANOVA test was conducted by SAS 9.2 for Windows, the authors agreed that the differences in plant material collection dates (early-ripening berries harvested in May and late-ripening in July) and the different times of sample runs in the laboratory must be given consideration as an important unaccounted for variable and their impact on actual data, and, thus, the appropriateness of the test. These two variables (time of collection, time of lab run) certainly influence the actual values obtained for AC, ACY, FRAP, etc. That said, "the large number of genotypes, samples and analyses certainly suggests some confidence in the major trends found in this study and in the conclusions reached." 
Table 1. Size of Fruits of 19 Genotypes of Vaccinium in Texas

\begin{tabular}{|c|c|c|}
\hline \multirow[t]{2}{*}{ Variety/Genotype } & \multicolumn{2}{|c|}{ Berry Number/100 g } \\
\hline & 2010 & 2009 \\
\hline $\begin{array}{l}\text { V. darrowii } \\
\text { (Darrow's)* }\end{array}$ & 362 & 397 \\
\hline $\begin{array}{l}\text { V. arboreum } \\
\text { (sparkleberry) } * *\end{array}$ & - & - \\
\hline $\begin{array}{l}\text { V. fuscatum } \\
\text { (black highbush)** }\end{array}$ & 654 & - \\
\hline $\begin{array}{l}\text { V. ashei } \\
\text { (rabbiteye) * }\end{array}$ & - & - \\
\hline Brightwell & 68 & 79 \\
\hline Climax & 74 & 105 \\
\hline Tifblue & 76 & 77 \\
\hline Premier & 67 & 100 \\
\hline Powderblue & 125 & 82 \\
\hline MS 63 & 56 & 58 \\
\hline Т 342 & 74 & 54 \\
\hline T 38 & 72 & 129 \\
\hline \multicolumn{3}{|l|}{$\begin{array}{l}\text { V. corymbosum hybrids } \\
\text { (Southern highbush) * }\end{array}$} \\
\hline MS 108 & 63 & 81 \\
\hline MS 122 & 88 & 82 \\
\hline MS 179 & 62 & - \\
\hline MS 231 & 75 & 66 \\
\hline MS 343 & 168 & - \\
\hline MS 546 & 137 & - \\
\hline MS 548 & 166 & - \\
\hline MS 611 & 122 & - \\
\hline
\end{tabular}

*in cultivation; $* *$ wild collected.

\section{RESULTS AND DISCUSSION}

\section{Variations of AC, ACY, and TPH in Fruits \\ With Genotype}

There were significant variations in AC (FRAP), TPH, and ACY contents in fruits among different species, cultivars, or selections (Tables 2-4). For both harvest years, the fruit of cultivated Darrow's blueberry had higher mean FRAP values (78.26 and $113.94 \mu \mathrm{mol} / \mathrm{g}$ in 2009 , and 2010 , respectively), followed by rabbiteyes (37.38 and 76.19 $\mu \mathrm{mol} / \mathrm{g}$, respectively) and then the southern highbush blueberry (26.67 and $52.45 \mu \mathrm{mol} / \mathrm{g}$, respectively) (Table 2). Among rabbitye cultivars and selections, MS 63 has highest $\mathrm{AC}$ values in fruits in both harvest years (45.76 and 91.75 $\mu \mathrm{mol} / \mathrm{g}$ in 2009 and 2010 , respectively), followed by T 38 $(86.22 \mu \mathrm{mol} / \mathrm{g}$ in 2010 and $40.01 \mu \mathrm{mol} / \mathrm{g}$ in 2009) and 'Tifblue' (33.05 and $88.19 \mu \mathrm{mol} / \mathrm{g}$ in 2009 and 2010, respectively). Among the five commercial cultivars, 'Tifblue' had the highest AC values while 'Premier' had the lowest AC values $(36.36$ and $55.30 \mu \mathrm{mol} / \mathrm{g}$ in 2009 and 2010 , respectively). This result was further confirmed by the comparison of data from both big and small berries (Table 5). The TPH and ACY contents in fruits generally showed a similar pattern (Tables 3-5).

In 'Tifblue' and 'Premier', less variation among FRAP, $\mathrm{TPH}$, and ACY in berries was observed between individual plants of the same genotype than among genotypes (Table 5).

\section{With Fruit Size}

$\mathrm{ACY}$ contents are significant contributors to $\mathrm{AC}$ of Vaccinium berries and are confined primarily to the skin of the fruit in Section Cyanococcus (highbush, lowbush, rabiteye) $[20,47]$. In our study, ACY in the mature berries of 'Powderblue' (rabbiteye) was primarily found in skins, but was also found in flesh (Table 6). In 'Powderblue', AC (FRAP, $\mu \mathrm{mol} / \mathrm{g})$ and TPH concentrations $(\mathrm{mg} / 100 \mathrm{~g})$ in the pulp were about $5.2 \%$ and $10.5 \%$ of those in the skin and seed, respectively (Fig. 2, Table 6). Thus, smaller berries with higher specific surface area have higher AC and TPH. Smaller berries of 'Tifblue' and 'Premier' had significantly higher AC (by 16-43\%) than bigger berries (Table 5). Statistical analysis by two-way ANOVA with genotypes and sizes as factors revealed significant differences $(p<0.005)$ between the berry size and the values of FRAP and TPH (no significant differences for ACY, $\mathrm{p}>0.05$ ). The regression analysis results also indicated that fruit size was significantly correlated to AC and TPH contents in these cultivars (Fig. 3).

Several studies suggest that ACY content is the major contributor to the higher antioxidant activity in smaller berries $[20,33,40,47]$. An inverse relationship was found between fruit size and ACY content in highbush [33,40] and cranberry [68]. However, in other studies no relationship between fruit size and ACY content in highbush [39,67] or lowbush blueberries [39] was found. It is further reported that fruit size was not correlated to ACY in rabbiteye, lowbush, velvet-leaf blueberry, oval-leaf blueberry, evergreen huckleberry, red huckleberry, black huckleberry and $V$. constablaei [33]. Moyer et al. (2002) reported that TPH was more highly correlated to AC than ACY [33]. Our results from rabbiteye blueberries ('Tifblue' and 'Premier') support this hypothesis (Table 5).

Fruit size is an important factor for differences in antioxidant activity within a genotype. In addition to fruit size, skin thickness, light condition, and other ecological factors might also influence AC when comparing different genotypes. It has been reported that wild Vaccinium usually have much higher AC than those in cultivation $[20,39]$. This hypothesis cannot be tested without comparative study of the same varieties in both wild and cultivated conditions. Evaluations of cultivated and wild huckleberries (V. membranaceum, V. delisciosum, and V. ovalifolum) in the Pacific Northwest [60] indicates that wild berries do not necessarily have higher antioxidant activity than cultivated berries of the same species. In this study, cultivated native $V$. darrowii 
Table 2. Antioxidant Capacity (FRAP) of Berries of Some Species, Cultivars, and Selections of Vaccinium in Texas

\begin{tabular}{|c|c|c|c|c|c|}
\hline $\begin{array}{l}\text { Species/ } \\
\text { Cultivars/Selections }\end{array}$ & \multicolumn{5}{|c|}{ FRAP $(\mu \mathrm{mol} / \mathrm{g})($ Mean \pm SD $)$} \\
\hline $\begin{array}{l}\text { V. darrowii } \\
\text { (Darrow's)* }\end{array}$ & $113.94 \pm 4.24$ & $78.26 \pm 4.53$ & $26.76 \pm 2.48$ & $37.10 \pm 1.57$ & $20.97 \pm 0.72$ \\
\hline $\begin{array}{l}\text { V. ashei } \\
\text { (rabbiteye) * }\end{array}$ & $76.19 \pm 12.01$ & $37.38 \pm 6.64$ & $46.61 \pm 12.98$ & $37.73 \pm 10.01$ & $13.84 \pm 2.65$ \\
\hline 'Brightwell' & $71.79 \pm 1.12$ & $24.69 \pm 3.05$ & $45.73 \pm 1.98$ & $24.81 \pm 0.92$ & $11.41 \pm 0.69$ \\
\hline 'Premier' & $55.30 \pm 1.38$ & $36.36 \pm 1.64$ & $37.26 \pm 8.07$ & $42.68 \pm 2.01$ & $10.86 \pm 0.61$ \\
\hline 'Powderblue' & $69.31 \pm 2.43$ & $39.02 \pm 2.15$ & $61.29 \pm 7.27$ & $36.26 \pm 1.21$ & $12.94 \pm 0.60$ \\
\hline MS 63 & $91.75 \pm 3.35$ & $45.76 \pm 5.27$ & $50.06 \pm 2.19$ & $55.67 \pm 2.03$ & $17.44 \pm 0.25$ \\
\hline T 342 & $71.83 \pm 4.41$ & $44.13 \pm 2.53$ & $66.38 \pm 2.04$ & $31.48 \pm 1.45$ & $18.13 \pm 2.16$ \\
\hline Т 38 & $86.22 \pm 0.73$ & $40.01 \pm 5.16$ & $34.22 \pm 0.98$ & $34.20 \pm 4.20$ & $14.32 \pm 0.40$ \\
\hline $\begin{array}{l}\text { V. corymbosum hybrids (southern } \\
\text { highbush)* }\end{array}$ & $52.45 \pm 8.16$ & $26.67 \pm 9.30$ & $41.67 \pm 6.31$ & $29.93 \pm 7.35$ & $11.57 \pm 2.56$ \\
\hline MS 108 & $41.97 \pm 0.42$ & $16.94 \pm 2.65$ & $35.73 \pm 0.93$ & $31.79 \pm 4.83$ & $9.44 \pm 0.66$ \\
\hline MS 546 & $57.75 \pm 1.05$ & - & - & - & - \\
\hline MS 548 & $55.38 \pm 2.24$ & - & - & - & - \\
\hline MS 611 & $45.51 \pm 1.08$ & - & - & - & - \\
\hline \multicolumn{6}{|l|}{ Others } \\
\hline 'Organic'*** & - & $35.63 \pm 3.11$ & - & - & - \\
\hline 'Driscolls'*** & - & $24.72 \pm 3.37$ & - & - & - \\
\hline 'Naturipe'*** & - & $35.96 \pm 1.59$ & - & - & - \\
\hline Mean & $67.24 \pm 1.85$ & $38.06 \pm 3.13$ & $43.72 \pm 2.61$ & $37.06 \pm 2.19$ & $13.87 \pm 0.93$ \\
\hline
\end{tabular}

*in cultivation; ** wild collected; *** purchased from a local grocery store; - no data collection.

('Nativeblue') had higher levels in FRAP, TPH, and ACY contents in both fruits and leaves than the native species $V$. fuscatum in the wild (Tables 2-4).

\section{With Fruit Maturity}

To date there has been limited research on the development of phenolic compounds and antioxidant activity during fruit maturation and ripening [74]. Castrejon et al. reported that antioxidant activity and TPH content tended to decrease during ripening [74]. However, in our analysis of the six species/cultivars grown in Texas, antioxidant activity of fruits decreased during ripening but TPH contents tended to increase with maturity. On average, mature berries have only $83 \%$ of the FRAP of green berries but have $114 \%$ of the TPH content found in green berries (Fig. 1, Tables 2-4, 7). This suggests that other non-phenolics are responsible for the higher antioxidant activity in green berries. 
Table 3. Total Phenolics (TPH) of Berries of Some Species, Cultivars, and Selections of Vaccinium in Texas

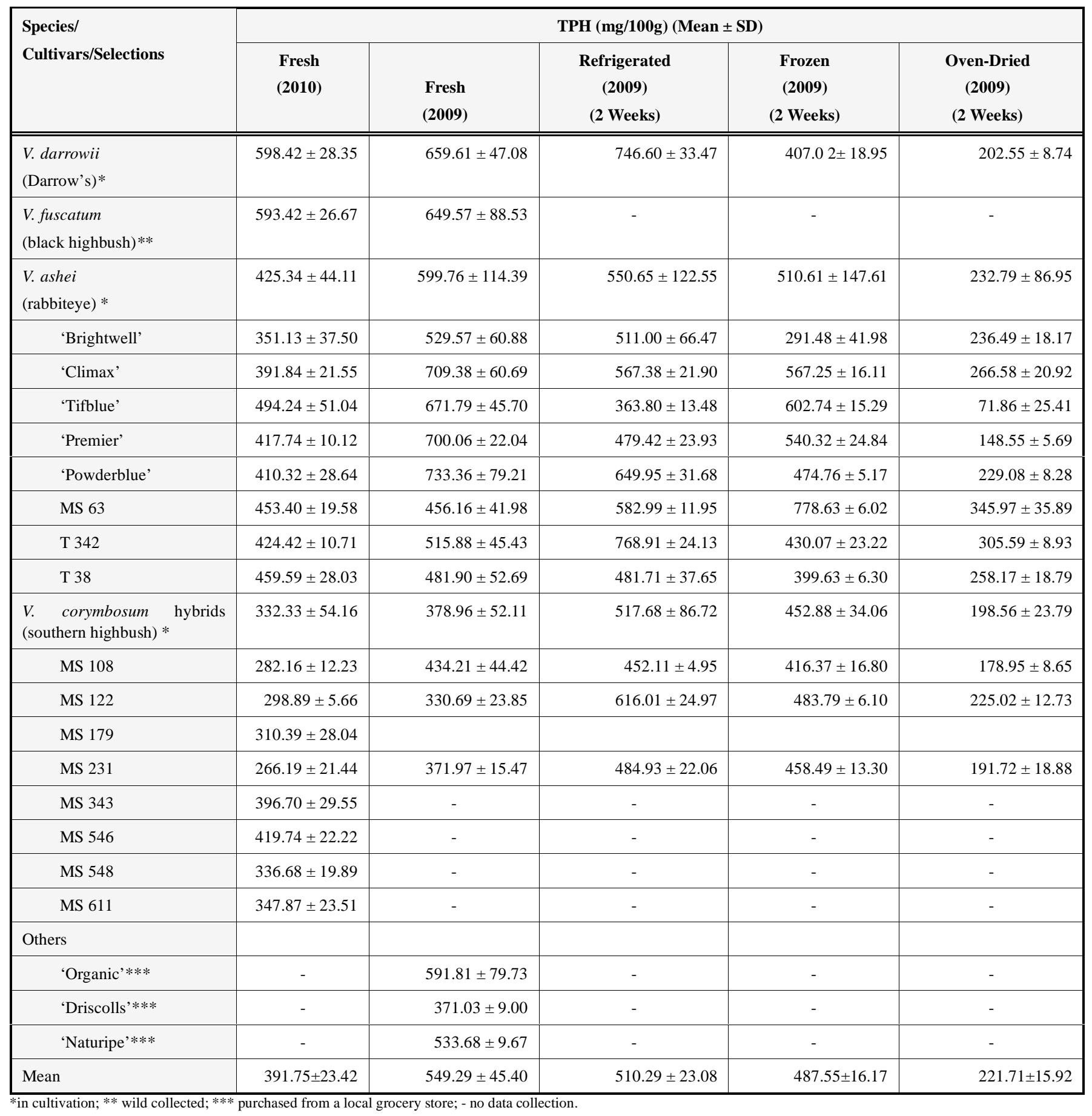

\section{With Storage}

On average, FRAP, ACY, and TPH values had no significant changes in storage at $4^{\circ} \mathrm{C}$ or freezing for two weeks. These results are consistent with other studies [56, 65, 69]. However, fruit dried at $65^{\circ} \mathrm{C}$ significantly reduced FRAP by 56.6-73.2\%, TPH by $47.6-69.3 \%$, and ACY by $38.1-67.4 \%$ in comparison to fresh berries (Tables 2-4).

\section{Variations of AC, ACY, and TPH in Leaves}

AC (FRAP) and TPH contents in leaves were significantly ( 3 to 15 times) higher than in fruit of the same geno- types which is consistent with previous studies [40]. However, the variation among of FRAP and TPH contents in leaves between the two harvest years were significantly greater than the variation attributed to genotypes: (Table 8). MS 343 and 'Tifblue' had the highest AC and TPH contents among the test genotypes.

\section{Total Soluble Sugars}

In general, there were no differences in soluble sugar among most genotypes, although 'Darrow's blueberry tended to have lower sugars (Table 9). 
Table 4. Total Anthocyanins (ACY) of Berries of Some Species, Cultivars, and Selections of Vaccinium in Texas

\begin{tabular}{|c|c|c|c|c|c|}
\hline \multirow{2}{*}{$\begin{array}{l}\text { Species/ } \\
\text { Cultivars/Selections }\end{array}$} & \multicolumn{5}{|c|}{$\operatorname{ACY}(\mathrm{mg} / 100 \mathrm{~g})(\mathrm{Mean} \pm \mathrm{SD})$} \\
\hline & $\begin{array}{l}\text { Fresh } \\
(\mathbf{2 0 1 0})\end{array}$ & $\begin{array}{l}\text { Fresh } \\
(2009)\end{array}$ & $\begin{array}{c}\text { Refrigerated } \\
\qquad(2009) \\
(2 \text { Weeks) }\end{array}$ & $\begin{array}{c}\text { Frozen } \\
(2009) \\
\text { (2 Weeks) }\end{array}$ & $\begin{array}{c}\text { Oven-Dried } \\
(2009) \\
\text { (2 Weeks) }\end{array}$ \\
\hline $\begin{array}{l}\text { V. darrowii } \\
\text { (Darrow's)* }\end{array}$ & $305.82 \pm 25.43$ & $516.86 \pm 23.37$ & $164.64 \pm 8.50$ & $424.00 \pm 19.60$ & $168.34 \pm 21.72$ \\
\hline $\begin{array}{l}\text { V. fuscatum } \\
\text { (black highbush)** }\end{array}$ & $206.19 \pm 45.24$ & - & - & - & - \\
\hline $\begin{array}{l}\text { V. ashei } \\
(\text { rabbiteye }) *\end{array}$ & $277.88 \pm 54.46$ & $392.92 \pm 57.19$ & $364.93 \pm 95.82$ & $326.97 \pm 95.99$ & $153.86 \pm 40.53$ \\
\hline 'Brightwell' & $213.63 \pm 3.11$ & $300.79 \pm 30.81$ & $372.33 \pm 4.00$ & $181.97 \pm 6.60$ & $141.36 \pm 8.93$ \\
\hline 'Climax’ & $304.00 \pm 2.22$ & $419.31 \pm 44.35$ & $391.93 \pm 10.56$ & $327.56 \pm 5.39$ & $121.35 \pm 6.34$ \\
\hline 'Tifblue' & $277.68 \pm 7.62$ & $361.45 \pm 5.62$ & $245.42 \pm 40.91$ & $476.85 \pm 9.24$ & $101.32 \pm 9.33$ \\
\hline 'Premier' & $225.49 \pm 3.69$ & $463.48 \pm 54.22$ & $270.80 \pm 18.11$ & $315.63 \pm 9.06$ & $131.57 \pm 9.64$ \\
\hline 'Powderblue' & $370.28 \pm 19.89$ & $363.63 \pm 59.86$ & $388.82 \pm 1.29$ & $279.05 \pm 0.23$ & $152.83 \pm 7.54$ \\
\hline MS 63 & $281.43 \pm 6.00$ & $385.74 \pm 42.85$ & $413.57 \pm 59.38$ & $452.56 \pm 75.91$ & $203.49 \pm 18.68$ \\
\hline Т 342 & $227.08 \pm 5.69$ & $473.66 \pm 82.23$ & $544.20 \pm 95.48$ & $301.91 \pm 15.95$ & $157.61 \pm 25.69$ \\
\hline Т 38 & $323.42 \pm 19.52$ & $375.32 \pm 41.23$ & $292.33 \pm 64.58$ & $280.26 \pm 18.51$ & $221.32 \pm 19.98$ \\
\hline $\begin{array}{l}V . \quad \text { corymbosum hybrids } \\
\text { (southern highbush) * }\end{array}$ & $188.71 \pm 42.64$ & $264.88 \pm 57.99$ & $359.67 \pm 55.24$ & $276.85 \pm 109.56$ & $163.96 \pm 77.05$ \\
\hline MS 108 & $130.87 \pm 3.69$ & $210.27 \pm 38.66$ & $295.98 \pm 15.43$ & $296.75 \pm 10.39$ & $247.31 \pm 12.56$ \\
\hline MS 122 & $142.20 \pm 1.18$ & $258.64 \pm 59.28$ & $394.52 \pm 1.31$ & $375.10 \pm 7.76$ & $149.26 \pm 14.69$ \\
\hline MS 179 & $182.98 \pm 6.34$ & - & - & - & - \\
\hline MS 231 & $180.83 \pm 5.88$ & $325.74 \pm 19.43$ & $388.52 \pm 83.15$ & $158.70 \pm 5.82$ & $95.32 \pm 8.65$ \\
\hline MS 343 & $263.81 \pm 4.86$ & - & - & - & - \\
\hline MS 546 & $211.40 \pm 3.62$ & - & - & - & - \\
\hline MS 548 & $218.38 \pm 6.72$ & - & - & - & - \\
\hline MS 611 & $179.19 \pm 5.71$ & - & - & - & - \\
\hline \multicolumn{6}{|l|}{ Others } \\
\hline 'Organic'*** & - & $607.58 \pm 105.92$ & - & - & - \\
\hline 'Driscolls' $* * *$ & - & $375.88 \pm 4.64$ & - & - & - \\
\hline 'Naturipe'*** & - & $537.15 \pm 10.71$ & - & - & - \\
\hline Mean & $237.56 \pm 7.72$ & $398.37 \pm 41.55$ & $343.11 \pm 33.56$ & $322.53 \pm 15.35$ & $157.59 \pm 13.65$ \\
\hline
\end{tabular}

*in cultivation; $* *$ wild collected; $* * *$ purchased from a local grocery store; - no data collection. 
Table 5. Antioxidant Activity, TPH, and ACY Contents of Different Size of Berries of 'Tifblue' and 'Premier'

\begin{tabular}{|c|c|c|c|c|c|c|c|c|}
\hline \multirow[t]{2}{*}{ Plant Sample } & \multicolumn{2}{|c|}{ Number/100g } & \multicolumn{2}{|c|}{ FRAP $(\mu \mathrm{mol} / \mathrm{g})($ mean \pm SD $)$} & \multicolumn{2}{|c|}{ TPH $(\mathrm{mg} / 100 \mathrm{~g})($ mean \pm SD $)$} & \multicolumn{2}{|c|}{$\operatorname{ACY}(\mathrm{mg} / 100 \mathrm{~g})($ mean \pm SD $)$} \\
\hline & Big & Small & Big & Small & Big & Small & Big & Small \\
\hline 'Tifblue' & 90 & 180 & $76.45 \pm 1.06$ & $101.98 \pm 7.46$ & $505.26 \pm 14.45$ & $623.20 \pm 29.74$ & $242.27 \pm 10.43$ & $267.15 \pm 5.70$ \\
\hline$\# 1$ & 94 & 192 & $77.68 \pm 3.76$ & $109.09 \pm 4.60$ & $519.24 \pm 20.39$ & $656.97 \pm 33.78$ & $253.59 \pm 30.47$ & $263.86 \pm 26.00$ \\
\hline$\# 2$ & 120 & 189 & $75.89 \pm 4.26$ & $102.62 \pm 3.99$ & $490.39 \pm 15.33$ & $611.74 \pm 20.73$ & $233.05 \pm 27.80$ & $263.86 \pm 11.93$ \\
\hline \#3 & 90 & 159 & $75.79 \pm 1.58$ & $94.22 \pm 3.14$ & $506.14 \pm 14.12$ & $600.89 \pm 17.48$ & $240.16 \pm 33.40$ & $273.73 \pm 4.79$ \\
\hline 'Premier' & 83 & 171 & $56.54 \pm 5.51$ & $71.65 \pm 2.38$ & $397.63 \pm 37.89$ & $513.91 \pm 14.08$ & $234.10 \pm 8.23$ & $249.64 \pm 9.71$ \\
\hline$\# 1$ & 82 & 165 & $62.37 \pm 1.67$ & $72.60 \pm 4.94$ & $425.96 \pm 8.28$ & $516.55 \pm 15.64$ & $241.34 \pm 8.89$ & $242.53 \pm 1.18$ \\
\hline \#2 & 90 & 185 & $55.84 \pm 4.50$ & $73.41 \pm 2.11$ & $412.34 \pm 6.23$ & $526.48 \pm 15.94$ & $225.15 \pm 23.74$ & $245.69 \pm 8.97$ \\
\hline \#3 & 78 & 162 & $51.42 \pm 2.11$ & $68.95 \pm 1.47$ & $354.59 \pm 26.15$ & $498.70 \pm 23.24$ & $235.81 \pm 5.34$ & $260.70 \pm 19.40$ \\
\hline
\end{tabular}

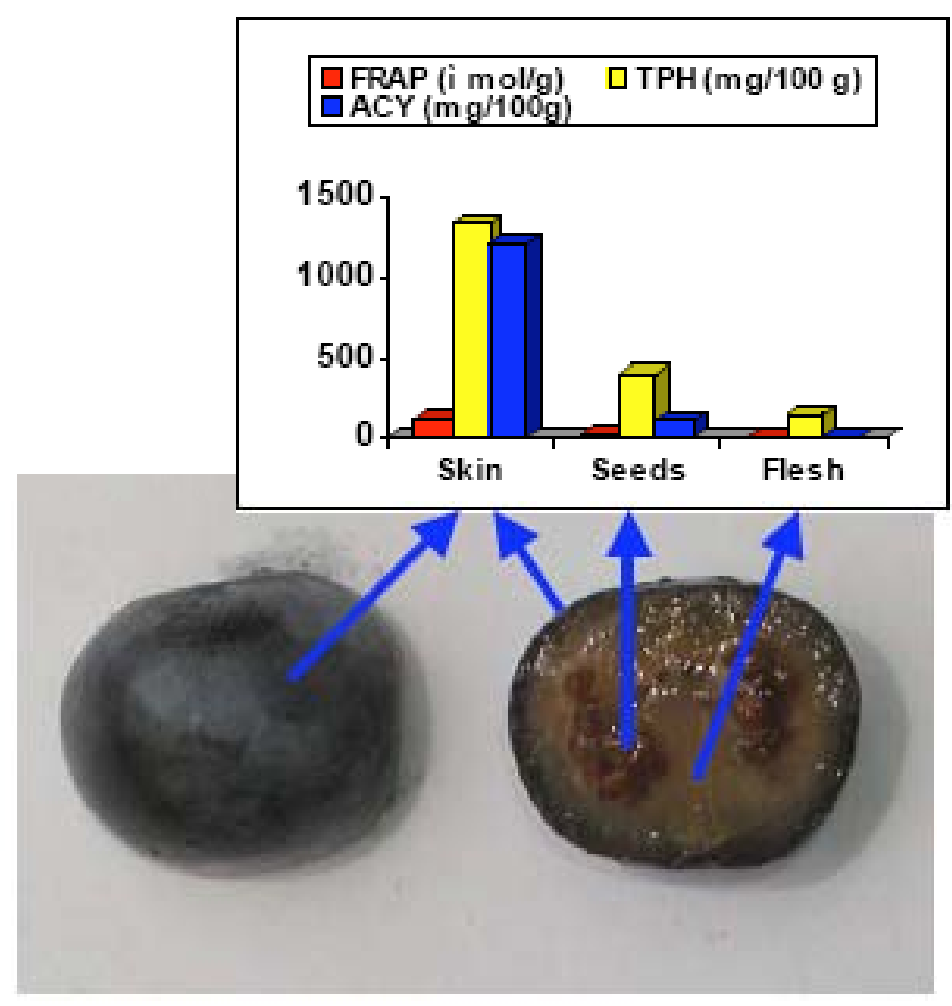

Fig. (2). Antioxidant capacity (AC) (in measurement of FRAP), total phenolics (TPH), and anthocyanins (ACY) contents in different parts of mature blueberries (photo by S.Y. Li).

Table 6. Antioxidant Activity, TPH, and ACY Contents of Different Parts of Berries of 'Powderblue'

\begin{tabular}{|l|c|c|c|}
\hline Part & FRAP $(\boldsymbol{\mu} \mathbf{m o l} / \mathbf{g})($ Mean \pm SD) & TPH $(\mathbf{m g} / \mathbf{1 0 0 g})($ Mean \pm SD $)$ & ACY $(\mathbf{m g} / \mathbf{1 0 0 g})(\mathbf{M e a n} \pm$ SD) \\
\hline \hline Seeds & $20.23 \pm 0.80$ & $398.83 \pm 53.79$ & $113.76 \pm 8.80$ \\
\hline Skin & $118.14 \pm 3.41$ & $1340.57 \pm 83.25$ & $1210.33 \pm 146.49$ \\
\hline Flesh & $6.22 \pm 0.33$ & $140.24 \pm 7.17$ & $-*$ \\
\hline Whole Berry & $47.99 \pm 3.17$ & $504.91 \pm 40.87$ & $435.72 \pm 22.75$ \\
\hline
\end{tabular}

*not detectable; - no data collection. 

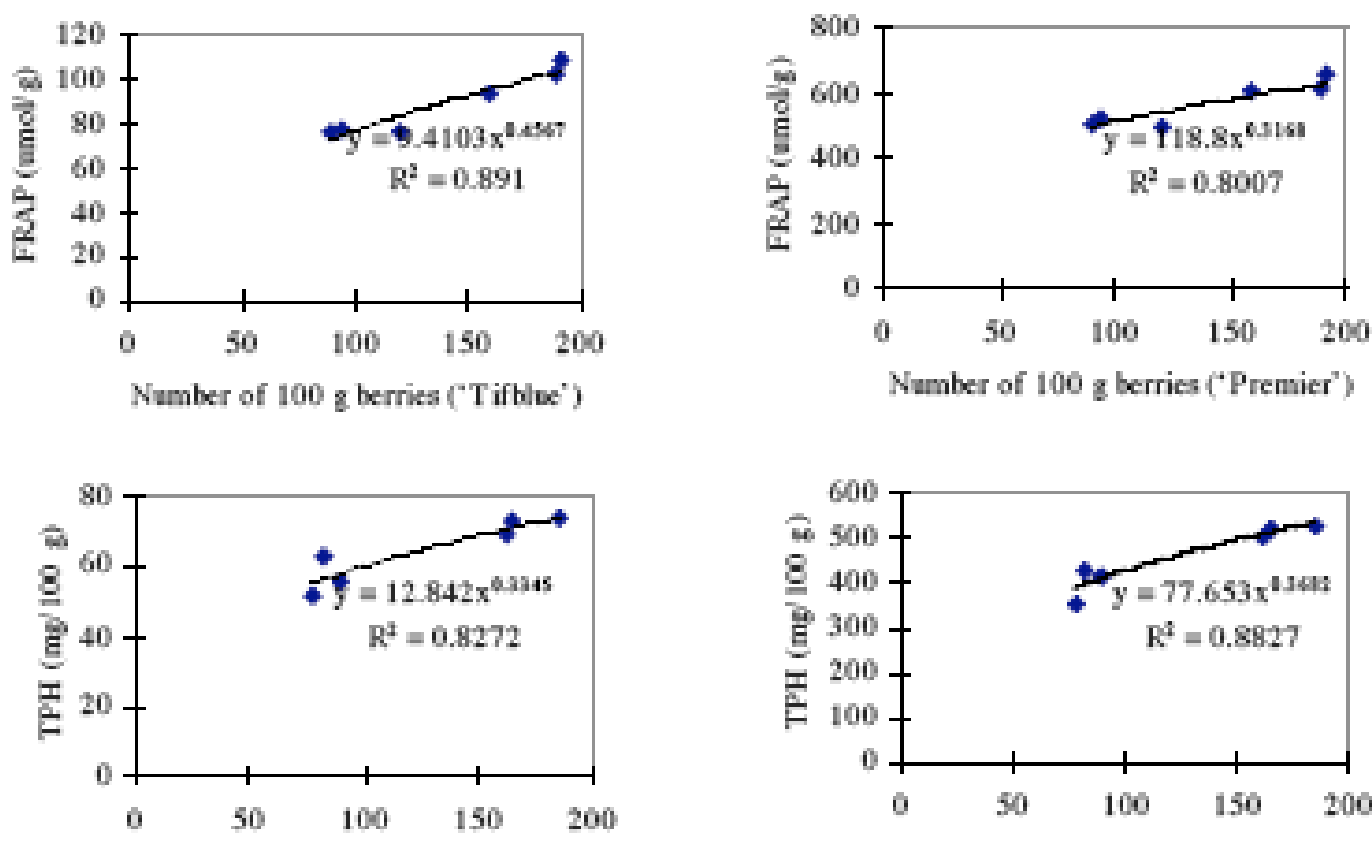

Number of $100 \mathrm{~g}$ berries ('Tifblac')

Number of $100 \mathrm{~g}$ berries ('Premier')
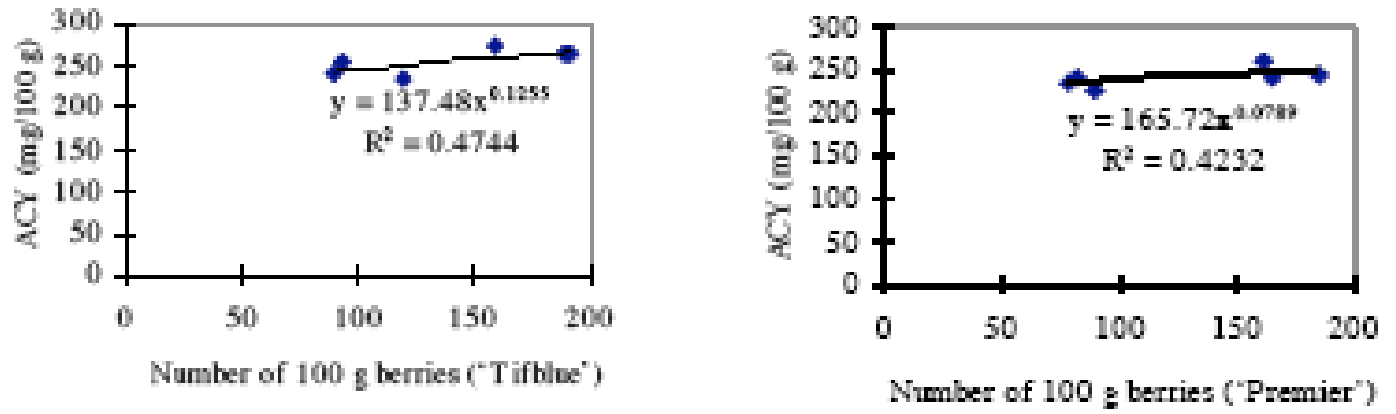

Fig. (3). 1a. The correlations between fruit size and antioxidant capacity (AC) (in measurement of FRAP) (1a: 'Tifblue'; 1b: 'Premier'), total phenolics (TPH) (2a: 'Tifblue'; 2b: 'Premier'), and total anthocyanins (ACY) (3a: 'Tifblue'; 3b: 'Premier'), respectively.

Table 7. Green Berries of Different Species, Cultivars, and Selections of Vaccinium

\begin{tabular}{|c|c|c|}
\hline $\begin{array}{l}\text { Species/ } \\
\text { Cultivars/Selections }\end{array}$ & $\begin{array}{c}\text { FRAP }(\mu \mathrm{mol} / \mathrm{g}) \\
(\text { Mean } \pm \text { SD })\end{array}$ & $\begin{array}{l}\text { TPH }(\mathrm{mg} / \mathbf{1 0 0 g}) \\
(\text { Mean } \pm \text { SD })\end{array}$ \\
\hline $\begin{array}{l}\text { V. darrowii } \\
\text { (Darrow's)* }\end{array}$ & $45.74 \pm 1.97$ & $552.94 \pm 45.01$ \\
\hline $\begin{array}{l}\text { V. fuscatum } \\
\text { (black highbush)** }\end{array}$ & $62.81 \pm 3.16$ & $852.43 \pm 106.64$ \\
\hline \multicolumn{3}{|l|}{$\begin{array}{l}\text { V. ashei } \\
\text { (rabbiteye)* }\end{array}$} \\
\hline 'Climax' & $57.27 \pm 1.50$ & $565.79 \pm 26.93$ \\
\hline 'Tifblue' & $52.61 \pm 2.17$ & $519.77 \pm 25.86$ \\
\hline 'Premier' & $42.62 \pm 1.20$ & $509.88 \pm 19.44$ \\
\hline 'Powderblue' & $64.76 \pm 2.66$ & $618.40 \pm 40.37$ \\
\hline Mean & $54.30 \pm 2.11$ & $603.20 \pm 44.04$ \\
\hline
\end{tabular}


Table 8. Antioxidant Activity and TPH of Leaves of Some Species, Cultivars, and Selections of Vaccinium in Texas

\begin{tabular}{|c|c|c|c|c|}
\hline \multirow{2}{*}{$\begin{array}{l}\text { Species/ } \\
\text { Cultivars/Selections }\end{array}$} & \multicolumn{2}{|c|}{ FRAP $(\mathrm{Mmol} / \mathrm{g})($ Mean \pm SD $)$} & \multicolumn{2}{|c|}{ TPH $(\mathrm{mg} / \mathbf{1 0 0 g})($ Mean \pm SD $)$} \\
\hline & 2010 & 2009 & 2010 & 2009 \\
\hline $\begin{array}{l}\text { V. darrowii } \\
\text { (Darrow's)* }^{*}\end{array}$ & $694.24 \pm 60.06$ & $582.59 \pm 10.80$ & $6092.34 \pm 848.02$ & $1952.28 \pm 39.04$ \\
\hline $\begin{array}{l}\text { V. arboreum } \\
\text { (sparkleberry) ** }\end{array}$ & $549.90 \pm 60.65$ & $401.53 \pm 7.03$ & $4927.25 \pm 240.41$ & $3674.25 \pm 456.45$ \\
\hline $\begin{array}{l}\text { V. fuscatum } \\
\text { (black highbush)** }\end{array}$ & $353.77 \pm 38.89$ & $353.32 \pm 35.50$ & $3759.40 \pm 133.64$ & $2756.79 \pm 534.52$ \\
\hline \multicolumn{5}{|l|}{$\begin{array}{l}\text { V. ashei } \\
\text { (rabbiteye) * }\end{array}$} \\
\hline 'Brightwell' & $936.43 \pm 27.61$ & $567.95 \pm 30.42$ & $7135.22 \pm 105.14$ & $1939.58 \pm 47.20$ \\
\hline 'Climax’ & $971.27 \pm 134.40$ & $512.14 \pm 17.57$ & $7828.47 \pm 640.75$ & $1747.52 \pm 38.60$ \\
\hline 'Tifblue' & $1008.34 \pm 40.17$ & $521.22 \pm 77.45$ & $7143.04 \pm 130.34$ & $1922.11 \pm 102.74$ \\
\hline 'Premier' & $910.28 \pm 32.19$ & $449.23 \pm 35.89$ & $6460.05 \pm 344.19$ & $2044.27 \pm 53.39$ \\
\hline 'Powderblue' & $659.43 \pm 52.51$ & $463.36 \pm 11.18$ & $6456.77 \pm 376.33$ & $2007.51 \pm 17.53$ \\
\hline MS 63 & $725.05 \pm 19.97$ & $774.96 \pm 14.24$ & $5949.12 \pm 162.52$ & $1998.11 \pm 58.81$ \\
\hline T 38 & $924.44 \pm 30.20$ & $555.98 \pm 16.99$ & $7946.80 \pm 410.56$ & $1936.62 \pm 44.47$ \\
\hline \multicolumn{5}{|c|}{$\begin{array}{l}\text { V. corymbosum hybrids } \\
\text { (southern highbush) } *\end{array}$} \\
\hline MS 108 & $706.01 \pm 34.66$ & $583.01 \pm 45.75$ & $4955.25 \pm 240.65$ & $1679.26 \pm 117.32$ \\
\hline MS 122 & $710.88 \pm 29.72$ & $557.53 \pm 51.08$ & $4218.20 \pm 287.88$ & $2214.91 \pm 76.67$ \\
\hline MS 179 & $300.03 \pm 7.25$ & & $2826.53 \pm 161.46$ & \\
\hline MS 231 & $866.83 \pm 20.85$ & $233.86 \pm 17.25$ & $6603.79 \pm 450.79$ & $1922.60 \pm 52.96$ \\
\hline MS 343 & $1183.22 \pm 59.29$ & $634.06 \pm 22.24$ & $9941.88 \pm 513.20$ & $1980.64 \pm 63.70$ \\
\hline MS 546 & $604.51 \pm 25.49$ & - & $6194.00 \pm 682.68$ & - \\
\hline MS 548 & $448.10 \pm 72.22$ & - & $4084.06 \pm 160.48$ & - \\
\hline MS 611 & $803.58 \pm 49.03$ & - & $6613.18 \pm 199.90$ & - \\
\hline Mean & $783.18 \pm 43.75$ & $530.97 \pm 30.37$ & $6279.08 \pm 354.97$ & $2283.82 \pm 147.64$ \\
\hline
\end{tabular}

Table 9. Soluble Sugar Contents in Mature Fruits of Different Species, Cultivars, and Selections of Vaccinium

\begin{tabular}{|l|c|c|}
\hline & \multicolumn{2}{|c|}{$\begin{array}{c}\text { Soluble Sugars } \\
\text { (\%, w/w, Mean } \pm \text { SD) }\end{array}$} \\
\hline $\begin{array}{l}\text { Species/ } \\
\text { Cultivars/Selections }\end{array}$ & $\mathbf{2 0 1 0}$ & $\mathbf{2 0 0 9}$ \\
\hline \hline $\begin{array}{l}\text { V. darrowii } \\
\text { (Darrow's)* }\end{array}$ & $10.28 \pm 0.83$ & $12.86 \pm 1.15$ \\
\hline $\begin{array}{l}\text { V. } \text { ashei } \\
\text { (rabbiteye) } *\end{array}$ & & \\
\hline \multicolumn{1}{|c|}{ 'Brightwell' } & $13.96 \pm 0.65$ & $12.00 \pm 1.64$ \\
\hline
\end{tabular}


Table 9. Contd....

\begin{tabular}{|c|c|c|c|}
\hline \multirow[b]{2}{*}{$\begin{array}{l}\text { Species/ } \\
\text { Cultivars/Selections }\end{array}$} & \multicolumn{2}{|c|}{$\begin{array}{c}\text { Soluble Sugars } \\
(\%, \text { w/w, Mean } \pm \text { SD })\end{array}$} & \\
\hline & 2010 & 2009 & \\
\hline 'Climax' & $12.65 \pm 0.86$ & & $12.70 \pm 0.29$ \\
\hline MS 108 & $14.00 \pm 0.58$ & & $14.68 \pm 1.56$ \\
\hline 'Premier' & $12.56 \pm 1.23$ & & $13.24 \pm 1.24$ \\
\hline 'Powderblue' & $9.36 \pm 1.09$ & & $12.48 \pm 1.48$ \\
\hline MS 63 & $14.49 \pm 1.19$ & & $15.97 \pm 1.28$ \\
\hline \multicolumn{4}{|l|}{$\begin{array}{l}\text { V. corymbosum hybrids } \\
\text { (southern highbush)* }\end{array}$} \\
\hline MS 122 & $12.91 \pm 0.75$ & & $14.70 \pm 0.31$ \\
\hline MS 179 & $11.10 \pm 1.71$ & & \\
\hline MS 231 & $13.21 \pm 0.49$ & & $13.99 \pm 1.14$ \\
\hline MS 343 & $13.51 \pm 0.92$ & & $13.35 \pm 1.06$ \\
\hline MS 546 & $15.36 \pm 1.23$ & - & \\
\hline MS 548 & $15.14 \pm 2.10$ & - & \\
\hline MS 611 & $14.42 \pm 0.82$ & - & \\
\hline
\end{tabular}

\section{CONCLUSIONS}

There were significant variations in $\mathrm{AC}$ (as measured by FRAP), TPH, and ACY contents in fruits among different genotypes, but less variation was detected among individual plants of the same genotype. Our results from analysis of rabbiteye blueberries support the hypothesis [33] that AC was more highly correlated to TPH than to ACY. Our analysis of six species/cultivars indicated that $\mathrm{AC}$ of fruits decreases during ripening but TPH contents tend to increase with maturity. Our findings are consistent with previous reports $[56,65,69]$ that AC, TPH, and ACY contents of berries do not change significantly during storage at $4^{\circ} \mathrm{C}$ or after freezing for two weeks, but decreases when dried at $65^{\circ} \mathrm{C}$ for $48 \mathrm{~h}$ or longer. AC and TPH contents in leaves of each test genotype were 3 to 15 times higher than in fruit of the same genotypes. MS 63 had the highest antioxidant activity and sugar levels in fruits, while MS 343 and 'Tifblue' were found to have the highest $\mathrm{AC}$ and $\mathrm{TPH}$ contents among the genotypes tested. These data could provide valuable information for the development of antioxidant pharmaceutical products.

\section{ACKNOWLEDGEMENTS}

The authors would like to thank H. Sunda of Mill Creek Blueberries, Nacogdoches, Texas, USA for assistance in data collection.

\section{ABBREVIATIONS}

$\begin{array}{ll}\text { AC }= & \text { Antioxidant capacity } \\ \text { ACY } & =\text { Anthocyanins } \\ \text { FRAP } & \text { Ferric reducing antioxidant power } \\ \text { ORAC } & \text { Xygen radical absorbance capacity } \\ \text { TPH } & =\text { Total phenolics } \\ \text { TPTZ } & =2,4,6 \text {-Tripyridyl-s-triazine }\end{array}$

\section{REFERENCES}

[1] Skupień, K.; Oszmiański, J.; Kostrzewa-Nowak, D.; Tarasiuk, J. In vitro antileukaemic activity of extracts from berry plant leaves against sensitive and multidrug resistant HL60 cells. Cancer Lett., 2006, 236 (2), 282-291.

[2] Katsube, N.; Iwashita, K.; Tsushida, T.; Yamaki, K.; Kobori, M. Induction of apoptosis in cancer cells by bilberry (Vaccinium myrtillus) and the anthocyanins. J. Agric. Food Chem., 2003, 51 (1), 68-75.

[3] Yi, W.; Fischer, J.; Krewer, G.; Akoh, C. C. Phenolic compounds from blueberries can inhibit colon cancer cell proliferation and induce apoptosis. J. Agric. Food Chem., 2005, 53 (18), 7320-7329.

[4] Bomser, J.; Madhavi, D. L.; Singletary, K.; Smith, M. A. L. In vitro anticancer activity of fruit extracts from Vaccinium species. Planta Med., 1996, 62 (3), 212-216.

[5] Neto, C. C. Cranberry and blueberry: Evidence for protective effects against cancer and vascular diseases. Mol. Nutr. Food Res., 2007, 51 (6), 652-664.

[6] Zhao, C.; Giusti, M. M.; Malik, M.; Moyer, M. P.; Magnuson, B. A. Effects of commercial anthocyanin-rich extracts on colonic cancer and nontumorigenic colonic cell growth. J. Aric. Food Chem., 2004, $52(20), 6122-6128$. 
[7] McKenzie, M.; Li, C.; Kaufman, P. B.; Seymour, E. M.; Kirakosyan, A. The use of selected medicinal herbs for chemoprevention and treatment of cancer, Parkinson's disease, heart disease, and depression. In Recent Advances in Plant Biotechnology, Kirakosyan, A.; Kaufman, P. B., Eds. Springer US: Springer, Dordrecht, Heidelberg, London, New York, 2009; pp 231-287.

[8] McKay, D. L.; Blumberg, J. B. Cranberries (Vaccinium macrocarpon) and cardiovascular disease risk factors. Nitru. Rev., 2008, 65 (11), 490-502.

[9] Martineau, L. C.; Couture, A.; Spoor, D.; Benhaddou-Andaloussi, A.; Harris, C.; Meddah, B.; Leduc, C.; Burt, A.; Vuong, T.; Le, P. L.; Prentki, M.; Bennett, S. A.; Arnason, J. T.; Haddad, P. S. Antidiabetic properties of the Canadian lowbush blueberry Vaccinium angustifolium Ait. Phytomedicine, 2006, 13 (9-10), 612-623.

[10] Wang, L.; Zhang, X. T.; Zhang, H. Y.; Yao, H. Y.; Zhang, H. Effect of Vaccinium bracteatum Thunb. leaves extract on blood glucose and plasma lipid levels in streptozotocin-induced diabetic mice. J. Ethnopharmacol., 2010, 130 (3), 465-469.

[11] Zafra-Stone, S.; Yasmin, T.; Bagchi, M.; Chatterjee, A.; Vinson, J. A.; Bagchi, D. Berry anthocyanins as novel antioxidants in human health and disease prevention. Mol. Nutr. Food Res., 2007, 51 (6), 675-683.

[12] Papandreou, M. A.; Dimakopoulou, A.; Linardaki, Z. I.; Cordopatis, P.; Klimis-Zacas, D.; Margarity, M.; Lamari, F. N. Effect of a polyphenol-rich wild blueberry extract on cognitive performance of mice, brain antioxidant markers and acetylcholinesterase activity. Behav. Brain Sci., 2009, 198, 352-358.

[13] Dugoua, J. J.; Seely, D.; Perri, D.; Mills, E.; Koren, G. Safety and efficacy of cranberry (Vaccinium macrocarpon) during pregnancy and lactation. Can. J. Clin. Pharmacol., 2008, 15 (1), e80-e86.

[14] Pérez-López, F. R.; Haya, J.; Chedraui, P. Vaccinium macrocarpon: An interesting option for women with recurrent urinary tract infections and other health benefits. J. Obstet. Gynaecol. Res., 2009, 35 (4), 630-639.

[15] Nowack, R.; Schmitt, W. Cranberry juice for prophylaxis of urinary tract infections - Conclusions from clinical experience and research. Phytomedicine, 2008, 15 (9), 653-667.

[16] Ross, S. M. Clinical applications of cranberry in urinary tract infections. Hollst. Nurs. Pract., 2006, 20 (4), 213-214.

[17] Ho, K. Y.; Huang, J. S.; Tsai, C. C.; Lin, T. C.; Hsu, Y. F.; Lin, C. C. Antioxidant activity of tannin components from Vaccinium vitisidaea L. J. Pharmacy Pharmacol., 2010, 51 (9), 1075-1078.

[18] Ho, K. Y.; Tsai, C. C.; Huang, J. S.; Chen, C. P.; Lin, T. C.; Lin, C. C. Antimicrobial activity of tannin components from Vaccinium vitis-idaea L. J. Pharmacy Pharmacol., 2010, 53 (2), 187-191.

[19] Sellappan, S.; Akoh, C. C.; Krewer, G. Phenolic compounds and antioxidant capacity of Georgia-grown blueberries and blackberries. J. Agric. Food Chem., 2002, 50, 2432-2438.

[20] Prior, R. L.; Cao, G. H.; Martin, A.; Sofic, E.; McEwen, J.; O'Brien, C.; Lischner, N.; Ehlenfeldt, M.; Kalt, W.; Krewer, G.; Mainland, C. M. ntioxidant capacity as influenced by total phenolic and anthocyanin content, maturity, and variety of Vaccinium species. J. Agric. Food Chem., 1998, 46, 2686-2693.

[21] Matchett, M. D.; MacKinnon, S. L.; Sweeney, M. I.; GottschallPass, K. T.; Hurta, R. A. R. Blueberry flavonoids inhibit matrix metalloproteinase activity in DU145 human prostate cancer cells. Biochem. Cell Biol., 2005, 83 (5), 637-643.

[22] MacLean, M. A.; Matchett, M. D.; Amoroso, J.; Neto, C.; Hurta, R. Cranberry (Vaccinium macrocarpon) flavonoids inhibit matrix metalloproteinases (MMPs) in human prostate cancer cells. FASEB J., 2007, 21, 791-795.

[23] Murphy, B. T.; MacKinnon, S. L.; Yan, X.; Hammond, G. B.; Vaisberg, A. J.; Neto, C. C. Identification of triterpene hydroxycinnamates with in vitro antitumor activity from whole cranberry fruit (Vaccinium macrocarpon). J. Agric. Food Chem., 2003, 51 (12), 3541-3545.

[24] Yan, X.; Murphy, B. T.; Hammond, G. B.; Vinson, J. A.; Neto, C. C. Antioxidant activities and antitumor screening of extracts from cranberry fruit (Vaccinium macrocarpon). J. Agric. Food Chem., 2002, 50 (21), 5844-5849.

[25] Neto, C. C.; Krueger, C. G.; Lamoureaux ${ }^{\text {T. L. }}$; Kondo, M.; Vaisberg, A. J.; Hurta, R. A. R.; Curtis, S.; Matchett, M. D.; Yeung, H.; Sweeney, M. I.; Reed, J. D. MALDI-TOF MS characterization of proanthocyanidins from cranberry fruit (Vaccinium macrocarpon) that inhibit tumor cell growth and matrix metalloproteinase expression in vitro. J. Sci. Food Agric., 2005, 86 (1), 18-25.
[26] Faria, A.; Pestana, D.; Teixeira, D.; de Freitas, V.; Mateus, N.; Calhau, C. Blueberry anthocyanins and pyruvic acid adducts: anticancer properties in breast cancer cell lines. Phytochem. Res., 2010.

[27] Jepson, R. G.; Mihaljevic, L.; Craig, J. Cranberries for preventing urinary tract infections (Cochrane Review). In The Cochrane $\mathrm{Li}$ brary, John Wiley \& Sons: Chichester, 2004.

[28] Lynch, D. M. Cranberry for prevention of urinary tract infections. Am. Fam.Physician 2004, 70 (11), 2175-2177.

[29] Jepson, R. G.; Craig, J. C. A systematic review of the evidence for cranberries and blueberries in UTI prevention. Mol. Nutr. Food Res., 2007, 51, 738-745.

[30] Takeshita, M.; Ishida, Y.; Akamatsu, E.; Ohmori, Y.; Sudoh, M.; Uto, H.; Tsubouchi, H.; Kataoka, H. Proanthocyanidin from Blueberry Leaves Suppresses Expression of Subgenomic Hepatitis C Virus RNA J. Biol. Chem., 2009, 284, 21165-21176.

[31] Canter, P. H.; Ernst, E. Anthocyanosides of Vaccinium myrtillus (Bilberry) for night vision-a systematic review of placebocontrolled trials. Surv. Ophthamol., 2004, 49 (1), 38-50.

[32] Muth, E. R.; Laurent, J. M. The effect of bilberry nutritional supplementation on night visual acuity and contrast sensitivity. Alter. Med. Rev., 2000, 5 (2), 164-173.

[33] Moyer, R. A.; Hummer, K. E.; Finn, C. E.; Frei, B.; Wrolstad, R. E. Anthocyanins, phenolics, and antioxidant capacity in diverse small fruits: Vaccinium, Rubus, and Ribes. J. Agric. Food Chem., 2002, 50, 519-525.

[34] Prior, R. L.; Wu, X. Anthocyanins: structural characteristics that result in unique metabolic patterns and biological activities. Free Radical Res., 2006, 40, 1014-1028.

[35] Piland, D. K. Characterization of phenolics and antioxidant capacity in blueberries: Effects of genotype, maturation and breeding. University of Arkansas, 2006.

[36] Eichholz, I.; Rohn, S.; Kroh, L. W.; Huyskens-Keil, S. Influence of location and fertilization on antioxidant acitivity in highbush blueberries (Vaccinium corymbosum L.). J. Appl. Bot. Food Qual., 2007, 81, 41-44.

[37] Howard, L. R.; Clark, J. R.; Brownmiller, C. Antioxidant capacity and phenolic content in blueberries as affected by genotype and growing season. J. Sci. Food Agric., 2003, 83, 1238-1247.

[38] Häkkinen, S. H.; Törrönen, A. R. Content of flavonols and selected phenolic acids in strawberries and Vaccinium species: influence of cultivar, cultivation site and technique. Food Res. Int., 2000, 33 (6), 517-524.

[39] Kalt, W.; Ryan, D. A. J.; Duy, J. C.; Prior, R. L.; Ehlenfeldt, M. K.; Vander Kloet, S. P. Interspecific variation in anthocyanins, phenolics, and antioxidant capacity among genotypes of highbush and lowbush blueberries (Vaccinium Section cyanococcus spp.). J. Agric. Food Chem., 2001, 49, 4761-4767.

[40] Ehlenfeldt, M. K.; Prior, R. L. Oxygen radical absorbance capacity (ORAC) and phenolic and anthocyanin concentrations in fruit and leaf tissues of highbush blueberry. J. Agric. Food Chem., 2001, 49 , 2222-2227.

[41] Wang, Z. Z.; Liu, J. B.; Lin, S. Y.; E.L., W. Study on extraction of flavanoids from Vaccinium uliginosum L. Food Sci., 2006, 2007 (11), 391-394.

[42] Meng, X. J.; Wang, X. C.; Li, Y. C. Study on extraction of flavanoids from leaves of Vaccinium uliginosum L. Sci. Technol. Food Ind., 2008, 2008 (1), 199-201.

[43] Li, M. J.; Lin, S. Y.; Wang, E. L.; Liu, J. B. Study on isolation and purification of anthocyanidin from Vaccinium uliginosum L. Food Sci., 2007, 28 (11), 139-141.

[44] Dong, Y. L.; Lin, S. Y.; Liu, Y. F.; Li, M. J.; Zhang, X. M.; Liu, X.; Liu, J. B. Study on optimization of extraction and purification of anthocyanidins from Vaccinium uliginosum L. by RP-HPLC. Food Sci., 2008, 29 (10), 349-352.

[45] Wang, L.; Yao, B. Y. Extraction and purification of flavone from the leaves of Vaccinium bracteatum Thunb. Food Ferm. Ind., 2004, 30 (9), 120-125.

[46] Hu, Z. J.; Cai, Z. H. Study on extraction technology of black pigment from Vaccinium bracteatum Thunb.leaf under microwave radiation. Chin. Wild Plant Res., 2007, 26 (6), 52-54.

[47] Kalt, W.; Forney, C. F.; Martin, A.; Prior, R. L. Antioxidant capacity, vitamin $\mathrm{C}$, phenolics, and anthocyanins after fresh storage of small fruits. J. Agric. Food Chem., 1999, 47, 4638-4644.

[48] Kalt, W.; McDonald, J. E.; Donner, H. Anthocyanins, phenolics, and antioxidant capacity of processed lowbush blueberry products. J. Food Sci., 2008, 65 (3), 390-393. 
[49] Chen, H. C.; Camire, M. E. Recovery of anthocyanins, pectin, and dietary fiber from cull lowbush blueberries. J. Food Quality, 2007, 20, 199-209.

[50] Nicoué, E. É.; Savard, S.; Belkacemi, K. Anthocyanins in wild blueberries of Quebec: extraction and identification. J. Agric. Food Chem., 2007, 55, 5626-5635.

[51] Lohachoompol, V.; Mulholland, M.; Srzednicki, G.; Craske, J. Determination of anthocyanins in various cultivars of highbush and rabbiteye blueberries. Food Chem., 2008, 111, 249-254.

[52] Remberg, S. F.; Haffner, K.; Blomhoff, R. Total antioxidant capacity and other quality criteria in blueberries CVS 'Bluecrop', 'Hardblue', 'Patroit', 'Putte', and 'Aron' after storage in cold store and controlled atmosphere. Acta Hort. (ISHS), 2003, 600, 595-598.

[53] Zheng, Y.; Wang, C. Y.; Wang, S. Y.; Zheng, W. Effect of highoxygen atmospheres on blueberry phenolics, anthocyanins, and antioxidant capacity. J. Agric. Food Chem., 2003, 51, 7162-7169.

[54] Taruscio, T. G.; Barney, D. L.; Exon, J. Content and profile of flavanoid and phenolic acid compounds in conjunction with the antioxidant capacity for a variety of Northwest Vaccinium berries. $J$. Agric. Food Chem., 2004, 52, 3169-3176.

[55] Giovanelli, G.; Buratti, S. Comparison of polyphenolic composition and antioxidant activity of wild Italian blueberries and some cultivated varieties. Food Chem., 2009, 112, 903-908.

[56] Scibisz, I.; Mitek, M. The changes of antioxidant properties in highbush blueberries (Vaccinium corymbosum L.) during freezing and long-term frozen storage. Acta Sci. Pol., Technol. Aliment., 2007, 6, 75-82.

[57] Dragović-Uzelac, V.; Savić, Z.; Brala, A.; Levaj, B.; Kovačević, D. B.; Biško, A. Određivanje udjela fenola i antioksidacijskog kapaciteta u sortama borovnice (Vaccinium corymbosum L.) uzgojenim na području sjeverozapadne Hrvatske. Food Technol. Biotechnol., 2010, 48, 214-221.

[58] Wang, B. C.; He, R.; Li, M. The stability and antioxidant activity of antocyanins from blueberry. Food Technol. Biotechnol., 2010, 48 (1), 42-49.

[59] Witzell, J.; Gref, R.; Näsholm, T. Plant-part specific and temporal variation in phenolic compounds of boreal bilberry (Vaccinium myrtillus) plants Biochem. Syst. Ecol., 2003, 31 (2), 115-127.

[60] Lee, J.; Finn, C. E.; Wrolstad, R. Anthocyanin pigment and total phenolic content of three Vaccinium species native to the Pacific Northwest of North America. Hort. Sci., 2004, 39 (5), 959-964.

[61] Bohm, B. A.; Koupai-Abyazani, M. R. Flavonoids and condensed tannins from leaves of Hawaiian Vaccinium reticulatum and $V$. calycinum (Ericaceae). Pacific Sci., 1994, 48 (4), 458-463.

[62] Zu, G. F.; Zhao, X. H.; Cui, S. N. Research of active substances about Vaccinium vitis-idaea $\mathrm{L}$. and its development and application. Chin. Bull. Life Sci., 2009, 21 (1), 151-155.
[63] Latti, A. k.; Kainulainen, P. S.; Hayirlioglu-Ayaz, S.; Ayaz, F. A.; Riihinen, K. R. Characterization of Anthocyanins in Caucasian Blueberries (Vaccinium arctostaphylos L.) Native to Turkey. J. Agric. Food Chem., 2009, 57, 5244-5249.

[64] USDA-ERS. U.S. Blueberry Industry 2010 http://usda.mannlib.cornell.edu/MannUsda/viewDocumentInfo.do? documentID=1765 (accessed July 22, 2010).

[65] Connor, A. M.; Luby, J. J.; Hancock, J. F.; Berkheimer, S.; Hanson, E. J. Changes in fruit antioxidant activity among blueberry cultivars during cold-temperature storage. J. Agric. Food Chem., 2002, 50, 893-898.

[66] Cho, M. J.; Howard, L. R.; Prior, R. L.; Clark, J. R. Flavonoid glycosides and antioxidant capacity of various blackberry, blueberry and red grape genotypes determined by high-performance liquid chromatography/mass spectrometry. J. Sci. Food Agric., 2004, 84, 1771-1782.

[67] Connor, A. M.; Luby, J. J.; Tong, C. B. S.; Finn, C. E.; Hancock, J. F. Genotypic and environmental variation in antioxidant activity, total phenolic content, and anthocyanin content among blueberry cultivars. J. Amer. Soc. Hort. Sci., 2002, 127 (1), 89-97.

[68] Wang, S. W.; Stretch, A. W. Antioxidant capacity in cranberry Is influenced by cultivar and storage temperature. J. Agric. Food Chem., 2001, 49 (2), 969-974.

[69] Lohachoompol, V.; Srzednicki, G.; Craske, J. The change of total anthocyanins in blueberries and their antioxidant effect after drying and freezing. J. Biomed. Biotech., 2004, 2004 (5), 248-252.

[70] Benzie, I. F. F.; Strain, J. J. The Ferric reducing ability of plasma (FRAP) as a measure of "antioxidant power": The FRAP assay. Anal. Biochem., 1996, 239, 70-76.

[71] Singleton, V. L.; Rossi Jr., J. A. Colorimetry of Total Phenolics with Phosphomolybdic-Phosphotungstic Acid Reagents. Amer. J. Enol. Vitic., 1965, 16, 144-158.

[72] Lee, J.; Durst, R.; Wrolstad, R. AOAC official method 2005.02: total monomeric anthocyanin pigment content of fruit juices, beverages, natural colorants, and wines by the $\mathrm{pH}$ differential method. In Official methods of analysis of AOAC International, Horowitz, H., Ed. AOAC: Washington D.C, 2005; Vol. 02.

[73] DuBois, M.; Gilles, K. A.; Hamilton, J. K.; Rebers, P. A.; Smith, F. Colorimetric Method for Determination of Sugars and Related Substances. Anal. Chem., 1956, 28 (3), 350-356.

[74] Castrejón, A. D. R.; Eichholz, I.; Rohn, S.; Kroh, L. W.; HuyskensKeil, S. Phenolic profile and antioxidant activity of highbush blueberry (Vaccinium corymbosum L.) during fruit maturation and ripening. Food Chem., 2008, 109, 564-572.

(C) Yuan et al.; Licensee Bentham Open.

This is an open access article licensed under the terms of the Creative Commons Attribution Non-Commercial License (http://creativecommons.org/ licenses/ by-nc/3.0/) which permits unrestricted, non-commercial use, distribution and reproduction in any medium, provided the work is properly cited. 